CORRECTION

\title{
Correction: Plectin ensures intestinal epithelial integrity and protects colon against colitis
}

Alzbeta Krausova, Petra Buresova, Lenka Sarnova, Gizem Oyman-Eyrilmez, Jozef Skarda, Pavel Wohl, Lukas Bajer, Eva Sticova, Lenka Bartonova, Jiri Pacha, Gizela Koubkova, Jan Prochazka, Marina Spörrer, Christopher Dürrbeck, Zuzana Stehlikova, Martin Vit, Natalia Ziolkowska, Radislav Sedlacek, Daniel Jirak, Miloslav Kverka, Gerhard Wiche, Ben Fabry, Vladimir Korinek and Martin Gregor

(c) The Author(s) 2021

Mucosal Immunology (2022) 15:373; https://doi.org/10.1038/s41385-021-00463-x

Correction to: Mucosal Immunology https://doi.org/10.1038/ s41385-021-00380-z, published online 05 March 2021

Informations about authors in the head of the article and affiliations section:

The afiliation of the co-author Daniel Jirak is currently incorrectly listed as University of Liberec, Faculty of Mechatronics Informatics and Interdisciplinary Studies, Liberec, Czech Republic. It shoul be Technical University of Liberec, Faculty of Health Studie, Liberec, Czech Republic.

\begin{abstract}
(c) (i) Open Access This article is licensed under a Creative Commons Attribution 4.0 International License, which permits use, sharing, adaptation, distribution and reproduction in any medium or format, as long as you give appropriate credit to the original author(s) and the source, provide a link to the Creative Commons license, and indicate if changes were made. The images or other third party material in this article are included in the article's Creative Commons license, unless indicated otherwise in a credit line to the material. If material is not included in the article's Creative Commons license and your intended use is not permitted by statutory regulation or exceeds the permitted use, you will need to obtain permission directly from the copyright holder. To view a copy of this license, visit http://creativecommons. org/licenses/by/4.0/.
\end{abstract}

(๑) The Author(s) 2021 